CUADERNOS DE ESTUDIOS GALLEGOS, LVIII N. ${ }^{\circ} 124$, enero-diciembre (2011), pp. 99-110

ISSN 0210-847 X

\title{
UNA OBRA MAESTRA DE LA ESCULTURA GÓTICA ITALIANA: EL CRUCIFICADO DE SANTA MARÍA DE MUROS (A CORUÑA)
}

\author{
FRANCISCO Singul
}

S.A. de Xestión do Plan Xacobeo (Xunta de Galicia) 


\title{
UNA OBRA MAESTRA DE LA ESCULTURA GÓTICA ITALIANA: EL CRUCIFICADO DE SANTA MARÍA DE MUROS (A CORUÑA)
}

\section{RESUMEN}

El monumental Crucificado gótico de Santa María del Camino (Muros) es la más importante representación conocida de la escultura toscana, en madera policromada, del siglo XIV. En este artículo se analizan la pieza y su contexto -en Italia y en Galicia-, el estilo del maestro y la iconografía. De igual modo también se tratan aspectos como el comercio bajomedieval entre Galicia e Italia, así como la importación de obras de arte del Mediterráneo.

PALABRAS CLAVE: crucifijo, escultura gótica, devoción, comercio exterior medieval, importación de obras de arte, Trecento, Toscana, Muros (Galicia, España)

\section{AN ITALIAN GOTHIC MASTERPIECE: THE CRUCIFIED JESUS CHRIST OF SANTA MARÍA DE MUROS (A CORUÑA)}

\begin{abstract}
The monumental gothic crucifix of Santa María del Camino (Muros) represents the major known work of tuscany XIVth century wood sculpture. In this paper the piece and its context -in Italy and Galicia-, the master style and iconographical aspects are analized. Late medieval foreign trade between Galicia and Italy as well as the import of mediterranean works of art are also considered.
\end{abstract}

KEY WORDS: crucifix, gothic sculpture, devotion, medieval foreign trade, import of works of art, Trecento, Tuscany, Muros (Galicia, Spain) 
Recibido/Received: 20/06/2011

Aceptado/Accepted: 27/07/2011

$\mathrm{E}$

L santuario muradano de la Virgen del Camino, templo tardogótico asociado al antiguo hospital de lazarados de Muros, conserva una magnífica imagen gótica de Cristo crucificado, obra de madera policromada y dimensiones monumentales $(200 \times 170 \mathrm{~cm})$, realizada con calidad excepcional por un maestro foráneo, ajeno al ambiente artístico gallego bajomedieval ${ }^{1}$. La pieza es acogida en una villa, la Puebla de Muro, que había sido de realengo durante un breve período, entre 1286-99, pero que a partir de entonces pasó al señorío arzobispal de Santiago de Compostela ${ }^{2}$. En el siglo XIV el enclave comienza a formar parte de las rutas comerciales de importación y exportación por vía marítima ${ }^{3}$; debido a su importancia estratégica en 1389 sufre el ataque del maestre de Avis, como consecuencia de la guerra entre Castilla e Inglaterra ${ }^{4}$, siendo reconstruida en época del arzobispo Juan García Manrique (1382-98). En las pri-

\footnotetext{
${ }^{1}$ Citado por C. MANSO PORTO, "Relevos e retábulos. Imaxinería", en Arte medieval (II), Galicia. Arte, t. XI, A Coruña, 1996, p. 452; le hemos dedicado especial atención, destacando que se trata, o bien de una obra local de inusual calidad, o de una pieza de importación llegada a Galicia por vía marítima, en F. SINGUL, "Cristo crucificado", en Luces de Peregrinación, catálogo de la exposición, Santiago, 2003, pp. 346-349. Posteriormente ya concretamos, por paralelos estilísticos, que la obra es de importación y que corresponde al buen hacer de un taller de Lucca; véase F. SINGUL, "Importazione di reliquie e opere d'arte a Compostella e in Galicia durante il medio evo e il rinascimento", en L. PARRINELLO, C. PAOLAZZI (coord.), Tradizione - Attualità nel Cammino di Santiago. Atti del Congresso Internazionale di Diffusione (Fondo, $22-24$ luglio 2006), Fondo, Trentino-Alto Adige, 2007, pp. 297-321, especialmente 314-317

2 En 1286 el rey Sancho IV de Castilla le otorgó la carta puebla conocida como fuero de Benavente; en 1299 el municipio de Muros pasa a titularidad arzobispal, por cesión de Fernando IV a la Iglesia de Santiago. Se evitó así entrar en rivalidades comerciales con el vecino puerto de Noia, perteneciente también a la Mitra compostelana; véase J. GARCÍA ORO, Galicia en los siglos XIV y XV, $t$. II: Galicia urbana. Ciudades episcopales, villas señoriales, municipios realengos, Pontevedra, 1987, pp. 183 y ss.

${ }^{3}$ De 1380 en adelante Muros exporta pescado e importa vinos del Mediterráneo, procedentes de la Corona de Aragón, con destino al mercado compostelano; véase E. FERREIRA PRIEGUE, Galicia en el comercio marítimo medieval, A Coruña, 1988, pp. 188-189

4 J. GARCÍA ORO, Galicia en los siglos XIV y XV, t. II, op. cit., p. 187
} 
meras décadas del siglo XV remonta su prosperidad y se construye en su centro urbano, entre 1402-6, su iglesia principal y futura colegiata, gracias a los auspicios del arzobispo Lope de Mendoza (1400-45). A fines del medievo Muros exporta pescado ahumado e importa vino y sal, como parte de un reducido y privilegiado grupo de villas costeras -Noia, Pontevedra y A Coruña- relacionadas con las rutas internacionales trazadas entre el Mar del Norte y el Mediterráneo ${ }^{5}$, en una época en la que comercio y peregrinación marítima eran actividades muy relacionadas ${ }^{6}$.

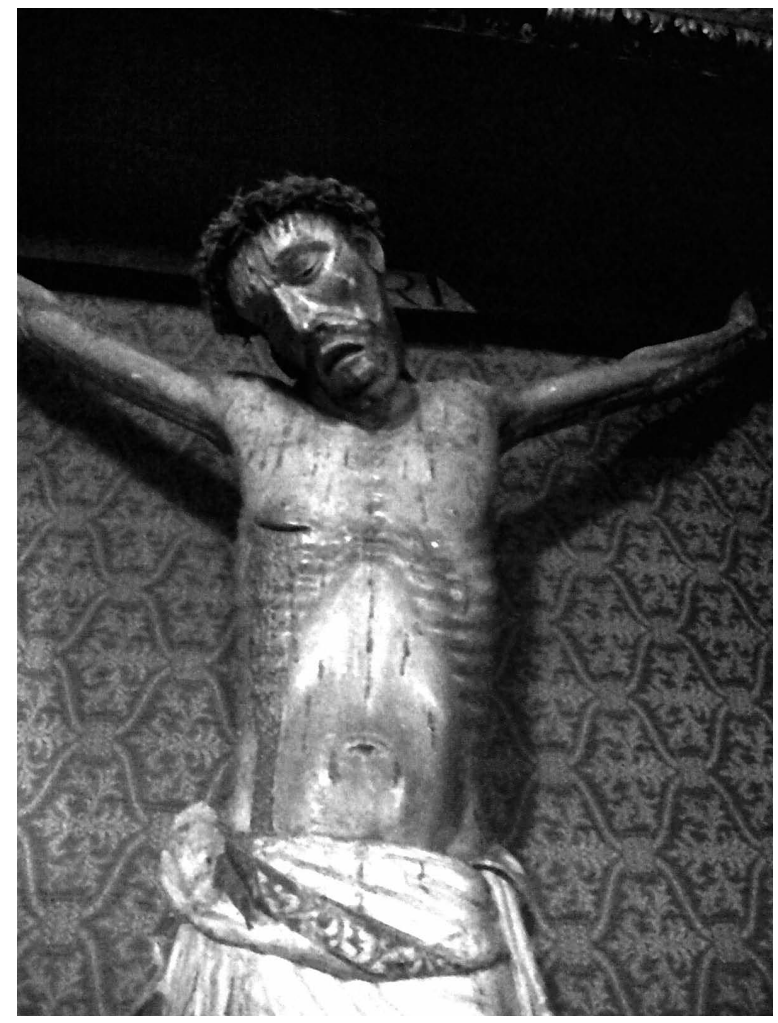

${ }^{5}$ E. FERREIRA PRIEGUE, Galicia en el comercio marítimo..., op. cit., 1988, pp. 467 y ss.; Idem, "El Patrón Santiago. Aproximación a la onomástica de los buques", Actas del II Congreso Internacional de Estudios Jacobeos. Rutas atlánticas de peregrinación a Santiago de Compostela (Ferrol, septiembre 1996), vol. II, Santiago, 1998, p. 51. A fines del siglo XV la marina mercante de Muros comerciaba con Inglaterra, Francia, Flandes e Italia, según R. DE ARTAZA MALVÁREZ, Muros. Páginas de su Historia, Madrid, 1923, p. 41

${ }^{6}$ E. FERREIRA PRIEGUE, Galicia en el comercio marítimo..., op. cit., 1988, pp. 185-186; F. SINGUL, Vino y cultura medieval: Galicia y los Caminos de Santiago, Santiago, 2010, pp. 59-64 
La ría de Muros ya había visto la llegada de naves con peregrinos en el siglo XII, los cruzados -peregrinos armados- que en 1147 y 1189 visitaron Compostela para solicitar la mediación del apóstol antes de partir a Tierra Santa ${ }^{7}$. A partir de 1361 se generalizan las peregrinaciones a Galicia desde los puertos británicos, con A Coruña como destino principal ${ }^{8}$, recepción de la que también pudieron participar los puertos episcopales de Noia y Muros, como sugieren los dos hospitales para pobres, enfermos y peregrinos fundados en Noia, y el que había en Muros $^{9}$, además del espital dos lazerados de Santa María do Camiño ${ }^{10}$ construido extramuros, en fecha indefinida del siglo XIV; constan ya en el siglo XV donaciones al lazareto muradano, como el legado que en 1421 firma Fernán Boom ${ }^{11}$. La fundación de este centro asistencial parece vinculada al flujo marítimo, y a su caridad se acogerían aquellos marineros, vecinos y extranjeros infectados con un mal que, en muchas ocasiones, se difundía a través de barcos y puertos. El ejercicio de la hospitalidad se completó en Muros con la fundación, en 1418, de un hospital para pobres y peregrinos situado en el centro urbano, iniciativa del juez Diego Rodríguez; un centro asistencial del que en 1423 era procurador Rodrigo Ares de Fisterra, quien había sido "palmeiro de Jherusalem, morador enno arrabalde desta dita villa de Muro..."12. No cabe duda, pues, del trasiego de gentes y mercancías, en época bajomedieval, entre esta villa costera y el Mediterráneo.

Teniendo como modelo tipológico el templo parroquial, levantado a principios del siglo XV, se construyó en el primer tercio del XVI la iglesia de Santa María del Camino, inmediata al lazareto ${ }^{13}$, edificio todavía en obras en

\footnotetext{
7 F. ALONSO ROMERO, "Las embarcaciones de la segunda Cruzada y su ruta atlántica desde Dartmouth hasta Galicia en 1147”, Actas del II Congreso Internacional de Estudios Jacobeos. Rutas atlánticas de peregrinación a Santiago de Compostela (Ferrol, septiembre 1996), vol. I, Santiago, 1998, pp. 69-70; HERBERS, K., "Cruzada y peregrinación. Viajes marítimos, guerra santa y devoción”, Actas del II Congreso Internacional de Estudios Jacobeos. Rutas atlánticas de peregrinación a Santiago de Compostela (Ferrol, septiembre 1996), vol. II, Santiago, 1998, pp. 32-34 y 38

8 C.M. STORRS, Jacobean pilgrims from England to St. James of Compostella. From the early twelfth to the late fifteenth century, Santiago, 1994, pp. 104-106; E. FERREIRA PRIEGUE, "La ruta ineludible: las peregrinaciones colectivas desde las Islas Británicas en los siglos XIV y XV", Actas del Congreso de Estudios Jacobeos (Santiago, octubre 1993), Santiago, 1995, pp. 280-289

9 A. POMBO RODRÍGUEZ, "Hospitales del fin del mundo", Peregrino, no 15-16 (1990); Idem, "Fisterra y Muxía: sendas jacobeas hacia el ocaso", Actas del III Congreso Internacional de Asociaciones Jacobeas (Oviedo, 9-12 octubre 1993), Oviedo, 1994, pp. 227-228; A. POMBO, X. FERNÁNDEZ CARRERA, J.M. YÁÑEZ, O Camiño dos Peregrinos á Fin do Mundo. A prolongación xacobea a Fisterra e Muxía, A Coruña, 2000, p. 33

10 J. GARCÍA ORO, Galicia en los siglos XIV y XV, t. II , op. cit., pp. 192-193

11 R. DE ARTAZA MALVÁreZ, Muros. Páginas..., op. cit., 1923, pp. 101-102

12 R. DE ARTAZA MALVÁREZ, Muros. Páginas..., op. cit., 1923, p. 328

13 Se trata de una iglesia de tipología marinera, inspirada en el modelo de la muradana excolegiata de Santa María do Campo (hoy parroquial de San Pedro de Muros); véase C. MANSO PORTO, "Arquitectura e escultura monumental: séculos XIV e XV”, en Arte medieval (II)..., op. cit., 1996, t. XI, p. 327
} 
$1567^{14}$, que devino santuario mariano de peregrinación al que acudían muchos devotos y sobre todo atribulados marineros con donaciones y exvotos buscando la protección de la Virgen ${ }^{15}$. En 1607, no obstante, el templo no despertó gran entusiasmo en el ánimo del cardenal Jerónimo del Hoyo, quien en su visita a la villa sólo dijo que "hay una hermita de Nuestra Señora del Camino con su órgano"16.

Es en este templo, cuya fachada se une al pequeño hospital por medio de un pasadizo elevado, donde se conserva una monumental escultura gótica en madera policromada de Cristo Crucificado, ubicado en un retablo barroco adosado en el muro del lado del Evangelio. La obra no tiene parangón con ninguna otra pieza de la imaginería gótica gallega, a excepción del Crucificado de la iglesia de Santa María del Campo de A Coruña -iglesia del gremio de mareantes, lo que puede ser significativo, y colegiata a partir de 1441-, catalogado por M.J. Carrasco Terriza dentro del segundo tercio del XIV y conservado en la actualidad en la capilla mayor de la iglesia del monasterio de La Rábida (Palos de la Frontera, Huelva), donde es conocido como el Cristo de los Remedios ${ }^{17}$.

Al igual que este ejemplar coruñés trasladado a La Rábida, el de Muros es un Crucificado gótico doloroso tallado en madera, el material más puro y noble para la cultura medieval, superior a la piedra y al metal, más cercano al hombre por ser un material vivo y asemejarse su naturaleza a la humana: vive, padece enfermedades, puede tener deformidades y al final muere ${ }^{18}$. En esta representación lígnea bajomedieval Cristo pende de la cruz muerto, con el cuerpo rígido, unido a los maderos por tres clavos. Presenta un tórax muy alargado, las costillas marcadas, el hueco epigástrico hundido y el vientre ligeramente abultado. De la herida del costado provocada por la lanzada (Jn 19, 31-37) mana la sangre en gruesos goterones coagulados. Los brazos son muy finos y se presentan totalmente extendidos, de modo que el estilizado cuerpo cuelga, tenso y sufriente, de músculos y tendones; las piernas, también muy finas, permanecen extendidas y rectas, con los pies cruzados, unidos

\footnotetext{
${ }^{14}$ Así lo prueba el testamento del mercader Juan Gill Durán, según M. FABEIRO GÓMEZ, "Muros", Gran Enciclopedia Gallega, t. XXII, s.f., p. 58

15 R. DE ARTAZA MALVÁREZ, Muros. Páginas..., op. cit., 1923, p. 121

16 J. DEL HOYO, Memorias del Arzobispado de Santiago, Santiago, 1607, fol. 318r.; edición de A. Rodríguez y B. Varela Jácome, Santiago, 1950, p. 330

17 M.J. CARRASCO TERRIZA, La escultura del Crucificado en la Tierra Llana de Huelva, Huelva, 2000, pp. 451-452, lám. 112. Pensamos que a este Crucificado se refiere Antonio de la Iglesia González en 1880 cuando habla del sepulcro de Andeiro, del siglo XIV, “...que está al lado del altar del $\mathrm{Sm}^{\circ}$ Cristo, en la Colegiata de la Coruña"; véase A. DE LA IGLESIA GONZÁLEZ, "Santa María del Campo de La Coruña", Estudios arqueológicos, Cuadernos de Estudios Gallegos, Anexo XXXIX, Madrid, CSIC, Instituto de Estudios Gallegos "Padre Sarmiento", 2008, p. 680 18 M. PASTOUREAU, Una historia simbólica de la Edad Media occidental, Buenos Aires, Katz, 2006, pp. $90-95$
} 
por un clavo y curvados en leve rotación interna. El Salvador viste largo y fino perizonio anudado a la cadera, que cae sin vuelo, cubriendo las piernas hasta las rodillas y permitiendo que la anatomía se transparente. La tela está decorada con una fimbria y rodea dos veces las piernas de Jesús, de modo que la segunda capa de lienzo forma una banda de pliegues diagonales, de derecha a izquierda, que se superponen a la parte del lienzo inferior, mientras que del nudo de la cadera derecha desciende una masa de plásticos y aristados pliegues, en contraste con la cadera contraria, de la cual pende blandamente uno de los bordes de la tela. La cruz original desapareció en fecha indeterminada, tal vez a fines del siglo XVII, cuando la imagen se ubica en un retablo de calle única flanqueada por columnas salomónicas, con una cruz carente de stipes superior. Fue tal vez en esa época cuando la cabeza recibe una desafortunada intervención, con la rebaja del cabello original, a base de gubia $\mathrm{u}$ otro instrumento, para que pudiese lucir una melena de pelo natural con corona de cuerda trenzada y largas púas. Esta lectura en clave barroca afectó también a la policromía bajomedieval, al ser repintada la imagen atendiendo a una puesta al día en la que los efectos de dramatismo no estarían muy alejados de los originales.

Tan expresiva imagen del momento culminante de la Pasión es fiel reflejo de una espiritualidad que procura el acercamiento del fiel a la divinidad, a través de la presentación sufriente y humana de Jesús, motivando de este modo una contemplación emotiva y piadosa ${ }^{19}$. La religiosidad occidental del siglo XIV favoreció la producción de impactantes crucifijos de gran formato, acordes con el concepto místico que inspiró a los imagineros de la época ${ }^{20}$, autores de unas tallas que aparecen en un dilatado ámbito regional -diferencias estilísticas aparte-, extendido desde Renania hasta Italia, pasando por Francia y la Península Ibérica ${ }^{21}$. En el cuerpo del Cristo gótico de Muros se aprecian las huellas de la Pasión -destacables son las llagas provocadas por los clavos, en especial en los pies, y la lanzada-, pero es en el rostro donde el padecimiento, la resignación y la muerte se representan

\footnotetext{
${ }^{19}$ El culto al cuerpo de Cristo y la emoción mística hacia la Pasión del Señor habían contado en Occidente con una promoción imparable desde el siglo XII, con Bernardo de Claraval como principal introductor, dándose en el siglo XIV una mayor necesidad de visualizar con fines devocionales los padecimientos del Salvador, en una época de decadencia del simbolismo; véase la valoración, publicada por vez primera en 1927, de J. HUIZINGA, El Otoño de la Edad Media. Estudios sobre la forma de la vida y del espíritu durante los siglos XIV y XV en Francia y en los Países Bajos, Madrid, 2005, pp. 251-252 y 267 y ss.

20 A. FRANCO MATA, "Crucifixus dolorosus". Cristo Crucificado, el héroe trágico del cristianismo bajomedieval, en el marco de la iconografía pasional, de la liturgia, mística y devociones", Quintana, 1 (2002), pp. 13-39, especialmente 16-23

${ }^{21}$ L. VÁZQUEZ DE PARGA, "El Crucifijo gótico doloroso de Puente la Reina", Príncipe de Viana, 12 (1943), pp. 307-313; A. FRANCO MATA; "El Crucifijo gótico doloroso de la iglesia de Santiago de Trujillo", Actas del VI Congreso de Estudios Extremeños, I. Historia del Arte, Cáceres-Badajoz, 1981, pp. 43-50; Idem, Escultura gótica española en el siglo XIV y sus relaciones con la Italia trecentista, Madrid, 1984, pp. 41 y ss.
} 
con maestría naturalista. El autor logró plasmar la honda tristeza de unos ojos que ya no ven, en un rostro de nariz afilada, pómulos marcados, mandíbula relajada y boca entreabierta, enmarcada por fina barba bífida, tan esquemática como la cabellera que cae por la nuca ${ }^{22}$. Es en la expresión del dolor matizado donde el escultor muestra de modo más sutil su talento, fruto de una sensibilidad artística muy alejada de la crueldad expresionista característica de los Crucifijos trecentistas de influencia germana ${ }^{23}$. Además de tan destacada calidad, hay que resaltar la diferencia estilística que presenta la pieza con respecto al resto de los Crucificados gallegos del siglo XIV, al tratarse de una obra muy alejada del discreto alcance de la escultura del país en dicha centuria. Esta excepcionalidad sumada a su parentesco estilístico con el ejemplar de La Rábida que perteneció a Santa María de A Coruña, hace pensar en un maestro o taller común a ambas imágenes, o por lo menos en artífices muy próximos, de no tratarse del mismo artífice.

Las comparaciones estilísticas con la escultura en madera de los reinos hispánicos sugieren que la imagen muradana no tiene un origen peninsular, siendo formalmente próxima, junto con el Cristo gótico de La Rábida, a la escuela de escultura lígnea que floreció durante el siglo XIV en territorio toscano, especialmente en Lucca y su entorno ${ }^{24}$. Las características formales de ambas piezas participan también del giottismo observado en la mayor parte de los Crucifijos de la pintura bajomedieval de Toscana y Emilia-Romagna, sugiriéndonos su excepcional calidad que se trata de obras producidas en un momento de gran desarrollo en la evolución de la escuela toscana trecentista en madera policromada. Los trazos estilísticos que asocian a estos Crucificados con el área toscana pueden verse ya en obras de los inicios del siglo XIV, como el Crucifijo de la iglesia de San Salvador della Misericordia (Lucca) ${ }^{25}$, y ya más concretamente en las piezas asociadas al llamado "maestro del Crucifijo de Camaiore" (141 x $137 \mathrm{~cm})^{26}$, activo en la primera mitad del Trecento, que definieron los parámetros técnicos, morfológicos y estilísticos en los que se integran cómodamente los dos Crucifijos italianos importados en Muros y A Coruña. La imagen que da nombre a la serie se encuentra en la iglesia de Santa

\footnotetext{
22 Aunque la cabellera original ha sido muy dañada, conserva la parte que cae por la espalda, con unas características semejantes al Cristo coruñés conservado en La Rábida; véase M.J. CARRASCO TERRIZA, La escultura del Crucificado..., op. cit., p. 451

${ }^{23}$ Una corriente originaria de Renania y Westfalia, según A. FRANCO MATA, "Cristus dolorosus", op. cit., 2002, pp. 27 y ss.

${ }^{24}$ F. SINGUL, "Importazione di reliquie e opere d'arte...", op. cit., 2007, p. 316

25 M. COLLARETA, "Crocifisso. Maestranza lucchese, sec. XIV, inizi", en C. BARACCHINI (dir.), Scultura lignea. Lucca 1200-1425, catálogo de la exposición (Lucca, Museo Nazionale di Palazzo Mansi - Museo Nazionale di Villa Guinigi, 16 dicembre 1995 - 30 giungno 1996), Firenze, 1995, vol. 1, p. 83

${ }^{26}$ G. PREVITALI, "Il Crocifisso di Camaiore", Bolletino d'arte, VI serie, LXVI, 11 (1981), pp. 119-122; Idem, Studi sulla escultura gotica in Italia, Torino, 1991, pp. 100-102
} 
Maria Assunta di Camaiore (Lucca), y a esta obra se asocian otros Crucificados lígneos toscanos, como el del duomo di Pietrasanta ${ }^{27}$, el Cristo de Cerreto Guidi (Florencia), el del duomo di Massa, el de la iglesia de San Domenico a San Miniato ${ }^{28}$ y otros del territorio luqués e incluso pisano, como es el caso del Crucificado de la parroquia de San Giovanni Apostolo e Evangelista (Santa Maria a Monte, Pisa). Cada pieza está esculpida en un único tronco de madera, excepto la cabeza, los brazos, las manos y los pies; por la posición de los brazos, S. Russo sugiere que las cruces originales tendrían forma de ipsilon ${ }^{29}$, como sucede con las germanas.

Aunque en un primer momento Lisner atribuyó este repertorio de escultura en madera policromada a la producción pisana de la segunda mitad del siglo XIV ${ }^{30}$, Severina Russo piensa que el taller del que salieron estas imágenes estaba ubicado en Lucca, puesto que la mayor parte de ellas se encuentran en su territorio, reconociendo, eso sí, que toda la cultura figurativa luquesa del Trecento es deudora del arte pisano ${ }^{31}$. Un estudio reciente, vinculado a la exposición en el Museo Diocesano de Milán (26 de febrero - 5 de abril de 2010) de un Crucificado del mismo estilo, datado en el segundo cuarto del siglo XIV, recoge un notable corpus iconográfico de estos Crucifijos monumentales salidos de Lucca y su entorno ${ }^{32}$.

La llegada a Galicia, por vía marítima, de dos piezas excepcionales procedentes de un taller de Lucca no debe extrañar. En las primeras décadas del siglo XV fueron relativamente frecuentes las arribadas de galeras venecianas en Cee, Muxía, A Coruña o Ferrol, y a estas localidades se desplazaban representantes del Cabildo compostelano para comprar telas de damasco que serían empleadas en la fabricación de ornamentos litúrgicos ${ }^{33}$; y lo que resulta más revelador, parece clara la importación por la misma vía de imágenes de devoción, como el célebre san Marcos de Corcubión, obra del Quattrocento realizado en Venecia o la Emilia-Romagna, comprada a unos comerciantes venecianos por los condes de Altamira, Rodrigo de

27 I. GIANELLI, Proposte per la conservazione ed il restauro del Crocifisso ligneo policromo del duomo di S. Martino di Pietrasanta, tesi di diploma presso l'Opificio delle Pietre Dure, Firenze, 1980, pp. 17-19

28 Al estudio de Severina Russo se debe la relación del maestro del Crucifijo de Camaiore con otros Crucificados lígneos de escuela pisana, como los del duomo di Pietrasanta, duomo di Massa, iglesia de San Domenico a San Miniato, etc.; véase S. RUSSO, "Nuove acquisizioni per il Maestro del Crocifisso di Camaiore", en C. BARACCHINI (dir.), Scultura lignea. Lucca 1200-1425, op. cit., 1995, vol. 1 pp. 109-118

29 S. RUSSO, "Nuove acquisizioni...", op. cit., 1995, p. 109

30 M. LISNER, Holzkruzifixe in Florenz und in der Toscana von der Zeit um 1300 bis zum frühen Cinquecento, München, 1970, p. 51

31 S. RUSSO, "Nuove acquisizioni...", op. cit., 1995, pp. 109 y 115

32 L. MAR, G. TIGLER, Un Crocifisso del Trecento lucchese: attorno alla riscoperta di un capolavoro medievale in legno, Milano, 2010

33 Esta importación de objetos sutuosos se documenta entre 1400 y 1426; véase A. LÓPEZ FERREIRO, Historia de la S.A.M. Iglesia de Santiago de Compostela, t. VII, 1905, pp. 106-108 
Moscoso y Juana de Castro para ser ubicada en la iglesia que en 1430 se construyó en las inmediaciones de su palacio y del puerto ${ }^{34}$. Un comercio de importación que es evocado y reinterpretado por la tradición popular en forma mirífica "aparición" sobre las olas, o en las playas, de imágenes como los Crucificados de Fisterra y Ourense, ambos del siglo XIV ${ }^{35}$, o de la propia imagen titular -una Virgen dormida- que preside el altar mayor del santuario de la Virgen del Camino de Muros. No cabe duda que en la creación de este mito, transmitido por tradición oral, late una realidad histórica: la importación de obras de arte vinculada a las rutas internacionales del comercio. Queda probado, además, que los marineros y comerciantes muradanos de fines de la Edad Media e inicios de la Moderna importaron piezas de valor, como la pila de agua bendita, de mármol blanco, que Gregorio López trajo de Génova en 1557, para donarla a Santa María del Camino ${ }^{36}$.

No queda claro, sin embargo, ni el destino original ni la fecha de llegada a Muros del Crucificado gótico. Resulta extraño que no hubiese llamado la atención de Jerónimo del Hoyo, de estar en el santuario a principios del siglo XVII. Se tiene constancia, no obstante, de la existencia de un "Sto. Cristo de estatura grande" en la iglesia del convento de San Francisco do Rial (Louro, Muros), imagen titular de uno de los cinco altares de este templo; en 1836, con motivo de la exclaustración de la comunidad franciscana de Louro, el Arzobispado de Santiago realizó un inventario de alhajas, ornatos e imágenes, entre los que figuraban un Crucificado de gran tamaño y una Virgen de los Dolores ${ }^{37}$, dejando a la custodia de don Roque Orxas, canónigo de la colegiata de Muros el citado "Sto. Cristo en grande" 38 . El traslado del

34 S. ARES ESPADA, "San Marcos", Galicia no Tempo, catálogo de la exposición, Santiago, 1990, p. 252; F. MAYÁN FERNÁNDEZ, H. GARCÍA PORTO y otros, "Corcubión", Gran Enciclopedia Gallega Silverio Cañada, t. XI, Lugo, 2003, pp. 140-141

35 Ambos Crucificados trecentistas, el de la iglesia de Santa María das Areas de Fisterra, y el de la capilla del Santo Cristo de la catedral de Ourense, obras foráneas según R. SÁNCHEZ AMEIJEIRAS, "A importación de obras de arte na Galicia tardomedieval”, Galicia, terra única. Galicia románica e gótica, Santiago, 1997, p. 313

${ }^{36}$ La pila tiene la siguiente inscripción: + ESTA PIESA TRVIO. PARI. ESTA IGLEZIA / GREGORIO LOPEZ ISVS MARINEROS. DENDE / GENUBA. ESTS ANO DE 1557. A. DIE. 4. IULIO; publicada por R. DE ARTAZA MALVÁREZ, Recuerdos de la Muy Noble, Muy Leal y Muy Humanitaria Villa de Muros, Santiago, 1908, p. 130

37 Archivo de la casa Giance-Patiño-Artaza. Legajo ${ }^{\circ}{ }^{3}$. Carpeta $1^{\mathrm{a}}$ : Año 1836. Inventario de alhajas, imágenes, ornamentos, etc. del Convento de San Francisco de Muros, hecho por orden de los Gobernadores del Arzobispado, por el Prior de la Colegiata de esta Villa después de la exclaustración, y oficios referentes a la supresión del Convento; el citado legajo indica que en ese momento la iglesia franciscana "tiene cinco altares que se denominan: el primero altar mayor, el $2^{\circ}$ el del Pilar o Angustias; el $3^{\circ}$ el de San Antonio; el $4^{\circ}$ el de la Purificación; y el $5^{\circ}$ el del Santo Cristo. Todos estos alttares y sus respectivos retablos han quedado y subsisten en la iglesia y solo se han removido de ellos aquellas imágenes que por no estar fixas podian fácilmente sustraerse". Del altar del Santo Cristo se retiraron en 1836 "la Virgen de los Dolores y el Sto. Cristo de estatura grande, y un Cristo pequeño de metal"; el documento fue publicado por R. DE ARTAZA MALVÁREZ, Muros. Páginas..., op. cit., 1923, pp. 331-336, especialmente 334-335

38 R. DE ARTAZA MALVÁREZ, Muros. Páginas..., op. cit., 1923, p. 337 
Crucificado y de la Dolorosa que lo acompaña a la iglesia de Santa María del Camino sería de todo punto posible, debido a que ya en esos años del siglo XIX era templo anexo de la colegiata ${ }^{39}$. El hecho de que entre 1806-1829 las obras realizadas en el interior del santuario se centrasen en el repinte del retablo de la Virgen, su camarín e imagen titular, sin ninguna mención al Crucificado ni a su retablo, ni tan siquiera a la reposición de aceite en una supuesta lámpara votiva, parece indicar que, en efecto, la talla de Cristo, la imagen de vestir de la Dolorosa y su retablo se incorporaron a la iglesia en años posteriores ${ }^{40}$. En 1895 la parroquia decide "componer un altar en la Virgen del Camino" 41 , noticia que sugiere que en ese año se formó un retablo juntando y ordenando diversas piezas y elementos; no se puede excluir como posibilidad que las imágenes que habían quedado en custodia del canónigo don Roque Orxas se reubicasen por esas fechas en el santuario de la Virgen del Camino.

La llegada del Crucificado gótico al convento franciscano de Muros, fundado en $1432^{42}$, pudo haberse realizado en algún momento del siglo XV o del $\mathrm{XVI}^{43}$, debido a la piedad de un donante - ¿un comerciante acaudalado?-, o al encargo de la comunidad, que quizá pudiese sufragarlo gracias a donaciones u ofrendas ${ }^{44}$. Parece significativo el ejemplo del santo Cristo de La Laguna, realizado hacia 1514 por

39 R. DE ARTAZA MALVÁreZ, Muros. Páginas..., op. cit., 1923, p. 167

40 Archivo Histórico Diocesano de Santiago (AHDS), Serie Administración Parroquial. San Pedro de Muros, $n^{\circ}$ 15: Obras pías y Santuario de la Virgen del Camino, 1806-1829. Esta documentación deja constancia pormenorizada de obras relativas al exterior del templo y su entorno (retejar, arreglo del atrio, colocación de un cruceiro), y por supuesto a su interior (lavado de ropa, obras de carpintería y cerrajería, repinte del retablo de la Virgen y de su imagen titular, reparación del camarín de la Virgen, gastos de cera y aceite para la lámpara de la Virgen...), sin mención alguna relativa al retablo del Crucificado y la Dolorosa, en el muro norte. Hay que reconocer que tampoco se dice nada del retablo lateral del muro sur, conjunto barroco dedicado a san José, acompañado por el arcángel Gabriel y san Ramón Nonato, con la Virgen del Carmen en el ático. El retablo mayor contaba, lógicamente, con el mayor favor de la parroquia. La devoción mariana favoreció el desarrollo de un ceremonial en el que "...el camarín de la Virgen se tapaba con unas finísimas telas de seda, descubriéndose sólo cuando el Cabildo de la Colegiata muradana celebraba misas mayores en el Santuario", según M. LAGO ÁLVAREZ, Santuario de la Virgen del Camino (Muros), Muros, 2010, p. 22 41 AHDS, Serie Administración Parroquial. San Pedro de Muros, no 4: Fábrica, 1857-1916, s.n.

42 Según el cronista Gonzaga en 1223 existía en el cabo Louro un eremitorio, germen del convento franciscano fundado en 1432 (en 1407, según el Padre Atanasio López); véase R. DE ARTAZA MALVÁREZ, Muros. Páginas..., op. cit., 1923, pp. 124-125 y 131

43 A mediados del siglo XVIII la mayoría de la flota de Muros estaba compuesta por lanchas dedicadas a la pesca de bajura, sin capacidad para desplazamientos a larga distancia, a excepción de ocho pataches y diez pinazas para el transporte de pescado hasta puertos cántabros y vascos. Esta realidad apenas cambió durante el siglo XIX, de suerte que en 1908 había prácticamente el mismo número de barcos; véase I. DUBERT, "El papel de la movilidad de la población en el ámbito semiurbano de la Galicia costero-occidental. La villa de Muros, siglos XVIII-XIX", en Dinámica Litorial-Interior. Actas XV Congreso de Geógrafos Españoles (Santiago, 15-19 setembro 1997), vol. II, Universidade de Santiago de Compostela, 1997, pp. 798-800

${ }_{44}^{4}$ La pobreza de esta comunidad franciscana es manifiesta en pleno siglo XVI, época en la que el Concejo acostumbraba a dar una limosna para el pan y la carne de los frailes; véase M. FABEIRO GÓMEZ, Páxinas históricas de Muros, Noia, Toxosoutos, 1997, p. 77 
Louis Van der Vule en un taller de los Países Bajos meridionales, transportado a Venecia y después a Barcelona, donde fue comprado por Juan Benítez -conquistador de La Palma y Tenerife- al mercader y capitán del barco que lo había llevado a la Ciudad Condal, antes de ser enviado a Cádiz y posteriormente a La Laguna, por obra del Adelantado don Alonso Fernández de Lugo, para ser donado en 1520 al convento franciscano de San Miguel de las Victorias ${ }^{45}$. La reconocida devoción cristológica de los franciscanos, guardianes de Tierra Santa, y la evocación permanente que realizan de la geografía sacra de la Pasión, tanto en Jerusalén como en Europa ${ }^{46}$ propiciaron en las afueras de Muros la ordenación de un catequizador Viacrucis, aprovechando un camino ascendente sacralizado con las correspondientes estaciones, que culmina en lo alto de monte Louro -Gólgota muradano- con un Calvario. El Cristo de madera policromada llegado de Italia que presidía uno de los altares de su iglesia conventual incidiría en esta espiritualidad evocadora de la Pasión, favorecedora de tantas formas de la religiosidad popular.

Sea como fuere, donación de un mercader o encargo de la comunidad, importado en la baja Edad Media o ya en el siglo XVI, hay que calificar sin género de dudas al Crucificado de la iglesia muradana de Santa María del Camino como una excepcional obra maestra de la plástica monumental en madera del Gótico italiano, realizada dentro de la tradición toscana por un excelente maestro luqués del segundo cuarto del siglo XIV.

\footnotetext{
45 F.J. GALANTE GÓMEZ, "Canarias, el Cristo de La laguna y sus relaciones con la escultura gótica tardía de los antiguos Países Bajos", Lumen Canariense. El Cristo de La laguna y su tiempo. Estudio crítico, I, Tenerife, Excmo. Ayuntamiento de San Cristóbal de La Laguna, 2003, pp. 217-261

${ }^{46}$ La tradición de los Sacromontes y Via Crucis (o Calvarios) realizados en Europa durante el Antiguo Régimen parte de los modelos piamonteses fundados por los franciscanos en Varallo (1491), Crea (1589) y Orta (1590). Se convirtieron en centros de peregrinaje y meditación, donde se reproducían los Santos Lugares de Jerusalén y/o se recreaban, en escenográficas capillas, con el recurso de la escultura, la pintura y la arquitectura, los episodios de la Pasión del Señor y, en el caso de Orta, la Vida de san Francisco, como imitación de la de Cristo. Sacromontes y Viacrucis estaban imbuídos de sensibilidad franciscana; proponían una recreación nostálgica y cercana al pueblo de los Santos Lugares a los que era difícil acceder a fines del siglo XV, debido a la expansión turca en Palestina. A fines del XVI, tras el Concilio de Trento y la peregrinación a Varallo del arzobispo de Milán Carlos Borromeo -canonizado en 1610-, se potencia la capacidad catequizadora de los Sacromontes, instrumentos piadosos que canalizan el fervor colectivo y las formas de la religiosidad popular; véanse M. BERNARDI, Il Sacro Monte di Varallo, Torino, 1960; M. COMETTI VALLE, P. BELLINI y V. COMOLI MANDRACCI, Iconografia del Sacro Monte di Varallo. Dipinti e incisioni dal XVI al XX secolo, Varallo, 1984; G. TESTORI y S. STEFANI PERRONE, Artisti del legno. La scultura in Valsesia dal XV al XVIII secolo, Borgosesia, 1985; F. CARESIO, I Sacri Monti del Piemonte, Torino, 1989; M. CENTINI, I Sacri Monti dell'area alpina italiana, Ivrea, 1990; S. LANGÈ y A. PENSA, Il Sacro Monte di Varallo, Milano, 1991; E. MASSONE (dir.), Sacri Monti in Piemonte. Itinerari nelle aree protette di Belmonte, Crea, Domodossola, Ghiffa, Orta, Varallo, Torino, 1994
} 